\title{
Withaferin a Triggers Apoptosis and DNA Damage in Bladder Cancer J82 Cells through Oxidative Stress
}

\author{
Tsu-Ming Chien ${ }^{1,2,3}$, Kuang-Han $\mathrm{Wu}^{4}$, Ya-Ting Chuang ${ }^{5}$, Yun-Chiao Yeh ${ }^{5}$, Hui-Ru Wang ${ }^{5}$, Bi-Wen Yeh ${ }^{2,3}$, \\ Chia-Hung Yen ${ }^{6}\left(\right.$ ) , Tzu-Jung Yu ${ }^{6}$, Wen-Jeng Wu ${ }^{1,2,3, *}$ and Hsueh-Wei Chang ${ }^{5,6,7, *(1)}$ \\ 1 Graduate Institute of Clinical Medicine, College of Medicine, Kaohsiung Medical University, \\ Kaohsiung 80708, Taiwan; u108801005@kmu.edu.tw \\ 2 Department of Urology, School of Medicine, College of Medicine, Kaohsiung Medical University, \\ Kaohsiung 80708, Taiwan; bewen90@yahoo.com.tw \\ 3 Department of Urology, Kaohsiung Medical University Hospital, Kaohsiung 80708, Taiwan \\ 4 Graduate Institute of Medicine, College of Medicine, Kaohsiung Medical University, \\ Kaohsiung 80708, Taiwan; u108500037@kmu.edu.tw \\ 5 Department of Biomedical Science and Environmental Biology, College of Life Science, \\ Kaohsiung Medical University, Kaohsiung 80708, Taiwan; u107023007@gap.kmu.edu.tw (Y.-T.C.); \\ u108551005@gap.kmu.edu.tw (Y.-C.Y.); whr0319@gmail.com (H.-R.W.) \\ 6 Graduate Institute of Natural Products, Kaohsiung Medical University, Kaohsiung 80708, Taiwan; \\ chyen@kmu.edu.tw (C.-H.Y.); u109831002@kmu.edu.tw (T.-J.Y.) \\ 7 Center for Cancer Research, Kaohsiung Medical University, Kaohsiung 80708, Taiwan \\ * Correspondence: wejewu@kmu.edu.tw (W.-J.W.); changhw@kmu.edu.tw (H.-W.C.); \\ check for
} updates

Citation: Chien, T.-M.; Wu, K.-H.; Chuang, Y.-T.; Yeh, Y.-C.; Wang, H.-R.; Yeh, B.-W.; Yen, C.-H.; Yu, T.-J.; Wu, W.-J.; Chang, H.-W. Withaferin a

Triggers Apoptosis and DNA

Damage in Bladder Cancer J82 Cells through Oxidative Stress.

Antioxidants 2021, 10, 1063. https:// doi.org/10.3390/antiox10071063

Academic Editors: Neven Zarkovic and Suzana Borović Šunjić

Received: 7 June 2021

Accepted: 29 June 2021

Published: 30 June 2021

Publisher's Note: MDPI stays neutral with regard to jurisdictional claims in published maps and institutional affiliations.

Copyright: (๑) 2021 by the authors. Licensee MDPI, Basel, Switzerland. This article is an open access article distributed under the terms and conditions of the Creative Commons Attribution (CC BY) license (https:// creativecommons.org/licenses/by/ $4.0 /)$.
Abstract: Withaferin A (WFA), the Indian ginseng bioactive compound, exhibits an antiproliferation effect on several kinds of cancer, but it was rarely reported in bladder cancer cells. This study aims to assess the anticancer effect and mechanism of WFA in bladder cancer cells. WFA shows antiproliferation to bladder cancer J82 cells based on the finding of the MTS assay. WFA disturbs cell cycle progression associated with subG1 accumulation in J82 cells. Furthermore, WFA triggers apoptosis as determined by flow cytometry assays using annexin V/7-aminoactinomycin D and pancaspase detection. Western blotting also supports WFA-induced apoptosis by increasing cleavage of caspases 3, 8, and 9 and poly ADP-ribose polymerase. Mechanistically, WFA triggers oxidative stress-association changes, such as the generation of reactive oxygen species and mitochondrial superoxide and diminishment of the mitochondrial membrane potential, in J82 cells. In response to oxidative stresses, mRNA for antioxidant signaling, such as nuclear factor erythroid 2-like 2 (NFE2L2), catalase (CAT), superoxide dismutase 1 (SOD1), thioredoxin (TXN), glutathione-disulfide reductase (GSR), quinone dehydrogenase 1 (NQO1), and heme oxygenase 1 (HMOX1), are overexpressed in J82 cells. In addition, WFA causes DNA strand breaks and oxidative DNA damages. Moreover, the ROS scavenger $N$-acetylcysteine reverts all tested WFA-modulating effects. In conclusion, WFA possesses anti-bladder cancer effects by inducing antiproliferation, apoptosis, and DNA damage in an oxidative stress-dependent manner.

Keywords: Withaferin A; bladder cancer; DNA damage; apoptosis; oxidative stress

\section{Introduction}

Urothelial carcinoma is the most common cancer in the urinary system, including the urinary bladder and upper urinary tract. Most urothelial carcinoma occurs in the urinary bladder, annually showing an estimated 550,000 new cases and 200,000 deaths. Most urinary bladder urothelial carcinoma is classified as non-muscle-involved bladder cancer (NMIBC), showing a high five-year survival of $96 \%$ for patients diagnosed early. Still, this survival dramatically decreases to $6 \%$ when tumor metastasis occurs [1]. However, these 
bladder cancer patients' mortality is high in advanced diseases, even surgery [2]. Therefore, novel drug development in bladder cancer therapy is warranted.

Several natural products and chemicals provide reactive oxygen species (ROS) modulation and induce apoptosis of cancer cells, which is valuable for anticancer treatment [3-8]. For example, Withaferin A (WFA) is a cell-permeable [9] steroidal lactone derivative from Withania somnifera, a traditional Indian Ayurvedic medicine used for centuries. WFA is a well-known antioxidant, anti-inflammatory [10], and anticancer [11-17] natural product with an ROS modulating ability $[12,18,19]$, but its antiproliferation function and mechanism in bladder cancer cells remains unclear.

In the present study, we investigated whether WFA exhibits an antiproliferation effect on bladder cancer cells. The urinary transitional cell carcinoma J82 cell line was used in vitro for evaluating antiproliferation and underlying WFA anticancer mechanisms in apoptosis, oxidative stress, antioxidant, and DNA damage systems. In addition, pretreatment with the ROS inhibitor $N$-acetylcysteine (NAC) elucidated the ROS modulating role of WFA. Therefore, this study sheds light on the antiproliferation function and mechanism of WFA in bladder cancer treatment.

\section{Materials and Methods}

\subsection{Cell Lines, Drugs, and Survival Assay}

The human urinary bladder urothelial carcinoma cell line (J82) was procured from the American Type Culture Collection (ATCC, Manassas, VA, USA). Cell culture conditions were Dulbecco's modified Eagle's medium containing 10\% fetal bovine serum in a $5 \% \mathrm{CO}_{2}$ atmosphere of a standard incubator.

WFA and apoptosis inhibitor Z-VAD-FMK (ZVAD) [20] were obtained from Selleckchem.com (Houston, TX, USA) and dissolved in dimethyl sulfoxide (DMSO). The antioxidant NAC (Sigma-Aldrich; St. Louis, MO, USA) was used to test the function of oxidative stress in WFA-induced changes. Cell survival was measured by the tetrazoliumbased MTS kit (Promega Corporation, Madison, WI, USA) [21].

\subsection{Cell Cycle Analysis}

Following $75 \%$ ethanol fixation, the DNA content of drug-treated cells was detected by staining with 7-aminoactinmycin D (7AAD) $(1 \mu \mathrm{g} / \mathrm{mL}, 30 \mathrm{~min})$ (Biotium; Hayward, CA, USA) [22] for Accuri C6 flow cytometry (Becton-Dickinson, Mansfield, MA, USA).

\subsection{Apoptotic Annexin $V / 7 A A D$ and Pancaspase Assays}

The Annexin V-stained and pancaspase-detected apoptotic cells were analyzed using the annexin V/7AAD kit [23] (Strong Biotech; Taipei, Taiwan) and generic caspase (caspases1 and 3 to 9) detecting kit [21] (Abcam, Cambridge, UK) as described by the user's manual for Accuri C6 flow cytometry.

\subsection{Apoptotic Western Blotting Assay}

The apoptosis sampler antibodies, including cleaved poly (ADP-ribose) polymerase (c-PARP), cleaved caspases-3 (c-Cas 3), c-Cas 9, and c-Cas 8, were used in 1:1000 dilution (Cell Signaling Technology, Inc., Danvers, MA, USA). In addition, a loading control mAb- $\beta$ actin antibody was purchased from Sigma-Aldrich (St. Louis, MO, USA). Other procedures for Western blotting were previously described [20].

\subsection{Cytometric ROS, Mitochondrial Superoxide (MitoSOX), and Mitochondrial Membrane Potential (MMP) Assays}

The ROS, MitoSOX, and MMP contents of drug-treated cells were detected by using $2^{\prime}, 7^{\prime}$-dichlorodihydrofluorescein diacetate (DCFH-DA; Sigma-Aldrich) [24] (10 $\mu \mathrm{M}, 30 \mathrm{~min}$ ), MitoSOX ${ }^{\mathrm{TM}}$ Red [25] (50 nM, $30 \mathrm{~min}$ ), and $\mathrm{DiOC}_{2}$ (3) [26] (Invitrogen; San Diego, CA, USA) ( $5 \mathrm{nM}, 30 \mathrm{~min}$ ), respectively. The contents were detected by Accuri $\mathrm{C} 6$ flow cytometry. 


\subsection{Real-Time PCR for Antioxidant Pathway Genes}

Total RNA was extracted and reverse-transcribed by using Trizol solution (Invitrogen) and an OmniScript RT kit (Qiagen, Valencia, CA, USA) [27]. The touch-down program [28] was performed for real-time PCR detection of the antioxidant genes [29,30], such as nuclear factor erythroid 2-like 2 (NFE2L2; NRF2), catalase (CAT), superoxide dismutase 1 (SOD1), thioredoxin (TXN), glutathione-disulfide reductase (GSR), quinone dehydrogenase 1 (NQO1), and heme oxygenase 1 (HMOX1), as previously mentioned [31]. The fold activation ( $\log 2)$ of antioxidant mRNA expression was calculated by the $2^{-\Delta \Delta C t}$ method [32] in reference to the GAPDH gene.

\subsection{Cytometric $\gamma H 2 A X$ and 8-Hydroxy-2-Deoxyguanosine (8-OHdG) Assays}

Following $75 \%$ ethanol fixation, the $\gamma \mathrm{H} 2 \mathrm{AX}$ [4] and 8-OHdG [33] contents of drugtreated cells were detected using Accuri $\mathrm{C} 6$ flow cytometry as previously described. Briefly, the $\gamma \mathrm{H} 2 \mathrm{AX}$ antibody [4] (Santa Cruz Biotechnology; Santa Cruz, CA, USA) $\left(4^{\circ} \mathrm{C}, 1 \mathrm{~h}\right)$ coupled with Alexa Fluor ${ }^{\circledR} 488$-conjugated secondary antibody (Cell Signaling Technology) and 7AAD incubation ( $5 \mu \mathrm{g} / \mathrm{mL}, 30 \mathrm{~min}$ ) were supplied to fixed cells. For 8-OHdG detection, fixed cells were provided with an 8-OHdG-FITC antibody (Santa Cruz Biotechnology) $\left(4^{\circ} \mathrm{C}, 1 \mathrm{~h}\right)$.

\subsection{Statistical Analysis}

The significance in multiple comparisons was determined by one-way analysis of variance (ANOVA) accompanied by Tukey HSD post hoc examination. Data labeled with different lower-case letters indicate significant differences.

\section{Results}

\subsection{WFA Inhibits Proliferation of Bladder Cancer Cells}

WFA reduces cell viability (\%) of bladder cancer J82 cells in dose-dependent manners (Figure 1). Pretreatment with the oxidative stress inhibitor NAC was performed to elucidate the dependence of oxidative stress on the antiproliferation function for WFA. WFA-induced antiproliferation in J82 cells at different concentrations was recovered to the normal proliferation condition by NAC (Figure 1).

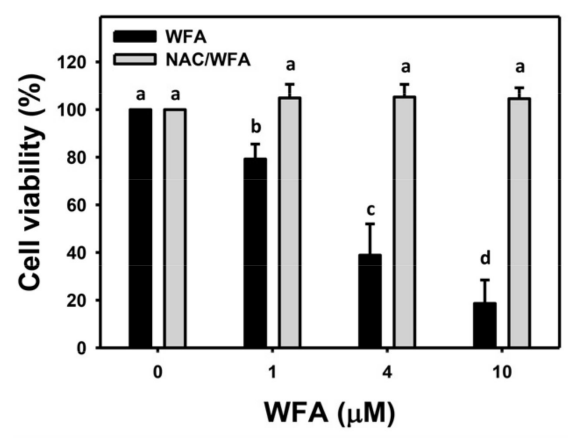

Figure 1. Cell viabilities of WFA in bladder cancer cells. The ROS inhibitor $N$-acetylcysteine (NAC) pretreated effect on the cell viability (24 h MTS assay) of bladder cancer cells (J82) following WFA incubation was also detected. Cells were pretreated with NAC $(8 \mathrm{mM}, 1 \mathrm{~h})$ and post treated with WFA (0 to $10 \mu \mathrm{M}$ for $24 \mathrm{~h}$ ), where the negative control for WFA $(0 \mu \mathrm{M})$ contained $0.1 \%$ DMSO. Data, mean $\pm \mathrm{SD}(n=3)$. Columns showing non-overlapping lower-case letters indicate $p<0.05$ for multiple comparisons. For example, WFA for 0, 1, 4, and $10 \mu \mathrm{M}$ treatments shows " $\mathrm{a}, \mathrm{b}, \mathrm{c}, \mathrm{d}$ ", indicating significant differences among each other because they do not overlap with the same lowercase letters. Similarly, WFA $1 \mu \mathrm{M}$ and NAC/WFA $1 \mu \mathrm{M}$ showing " $a$ " and " $b$ " indicate significant differences among each other. 


\subsection{WFA Accumulates SubG1 and G2/M Populations in Bladder Cancer Cells}

The profiles for the bladder cancer cell cycle following WFA incubation are shown (Figure 2A). The bladder cancer J82 cells exposed to different concentrations of WFA induced more subG1 and G2/M cells than the control (Figure 2B).
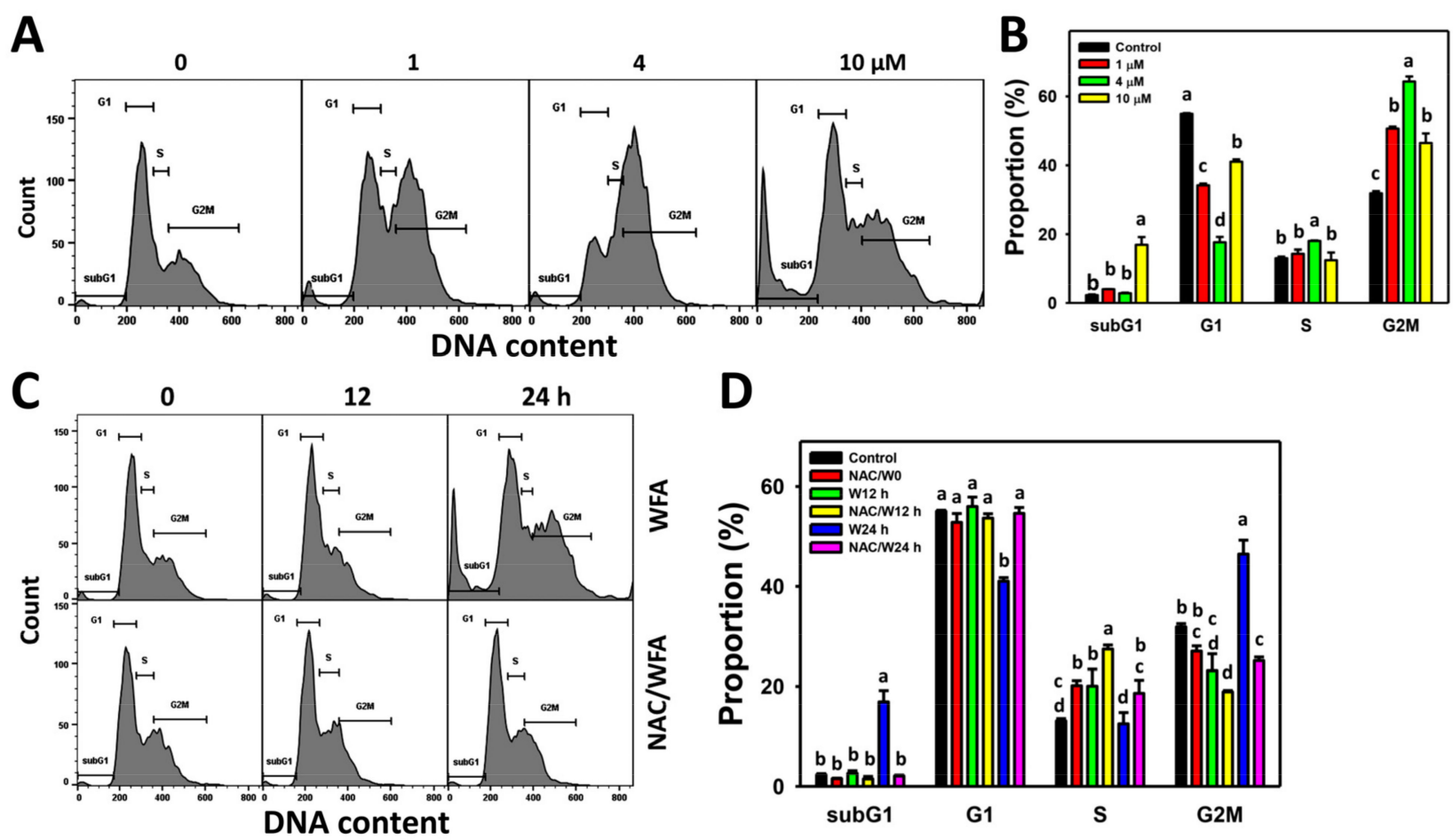

D

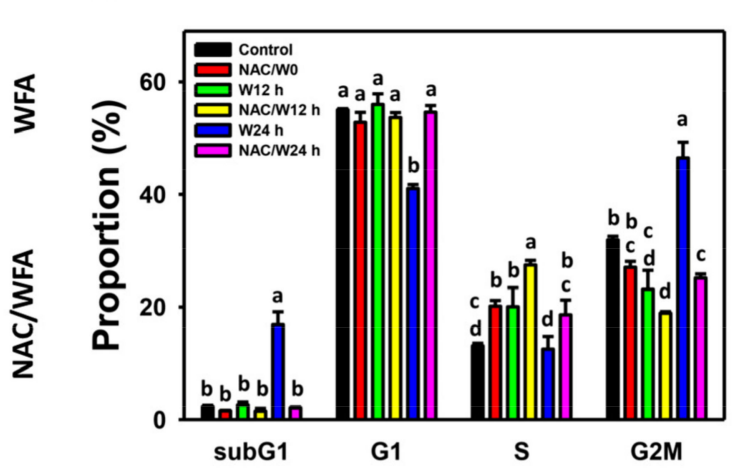

Figure 2. Cell cycle effect of WFA in bladder cancer cells. (A,B) Patterns and statistics for the cell cycle. Bladder cancer cells (J82) were treated with WFA $(24 \mathrm{~h}, 0$ to $10 \mu \mathrm{M})$, where the negative control for WFA $(0 \mu \mathrm{M})$ contained $0.1 \%$ DMSO. (C,D) Pattern and statistics for NAC pretreated effects on the cell cycle of J82 cells following WFA incubation. Cells were pretreated and post treated with NAC $(8 \mathrm{mM}, 1 \mathrm{~h})$ and WFA $(0$ and $10 \mu \mathrm{M}$ for 12 and $24 \mathrm{~h})$, respectively. They were labeled with NAC/W0, NAC/W12 h, and NAC/W24 h. Data, mean \pm SD $(n=3)$. Columns showing non-overlapping lower-case letters, indicating $p<0.05$ for multiple comparisons of the same cell cycle phase. In the example of subG1 in Figure 2D, the W24 h treatment shows " $a$ " while others show " $b$ ", indicating that W24 h significantly differed from others. Among non-W24 $\mathrm{h}$ treatments, their labeling letters are overlapping with " $\mathrm{b}$ ". Therefore, it shows nonsignificant differences between each other.

The cell cycle profiles for bladder cancer cells following NAC pre-incubation, WFA post-incubation, or both are demonstrated (Figure 2C). The bladder cancer J82 cells exposed for different incubation times of WFA induced more subG1 and G2/M cells at $24 \mathrm{~h}$ after WFA treatment than the control, which was inhibited by NAC pretreatment (Figure 2D).

\subsection{WFA Triggers Annexin V-Related Apoptosis in Bladder Cancer Cells}

The annexin $\mathrm{V} / 7 \mathrm{AAD}$ profiles for bladder cancer cells following WFA incubation are shown (Figure 3A). The bladder cancer J82 cells exposed to different concentrations of WFA induced more annexin $\mathrm{V}(+)$ cells than the control (Figure 3B). 


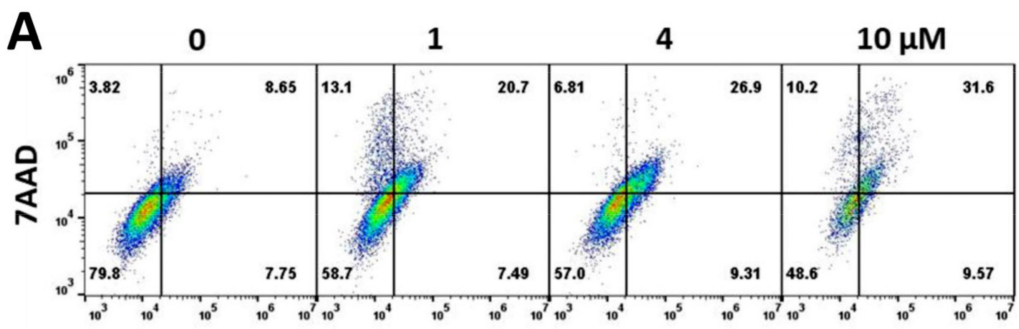

Annexin V intensity

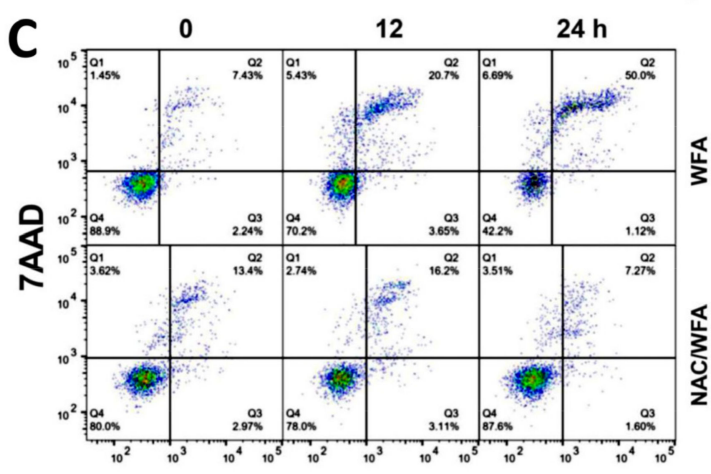

Annexin V intensity

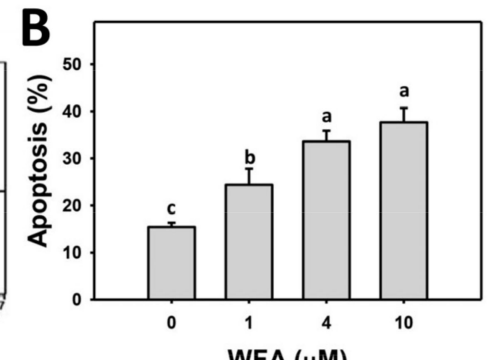

WFA $(\mu \mathrm{M})$

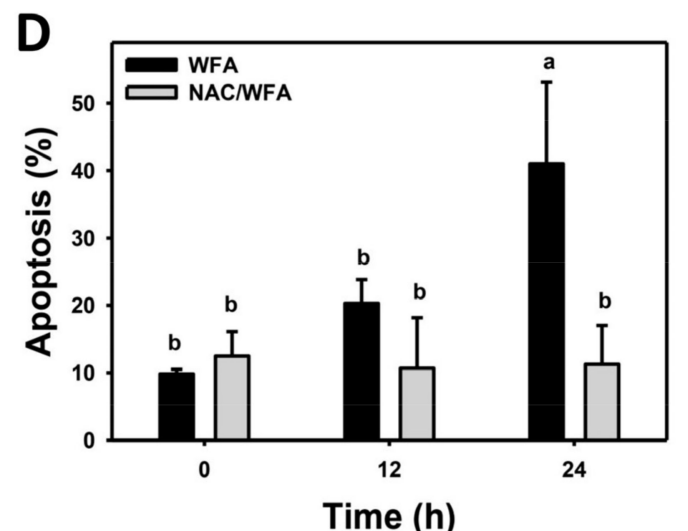

Figure 3. WFA induces apoptosis in bladder cancer cells. (A,B) Patterns and statistics for annexin V change. Bladder cancer cells (J82) were treated with WFA $(24 \mathrm{~h}, 0$ to $10 \mu \mathrm{M})$, where the negative control for WFA $(0 \mu \mathrm{M})$ contained $0.1 \%$ DMSO. Annexin V (+)/7AAD (+/-) populations (\%) were regarded as apoptosis (\%). (C,D) Pattern and statistics for the NAC pretreated effect on annexin $\mathrm{V}$ expression of $\mathrm{J} 82$ cells were identified following WFA incubation. Cells were pretreated and post treated with NAC ( $8 \mathrm{mM}, 1 \mathrm{~h})$ and WFA $(0$ and $10 \mu \mathrm{M}$ for 12 and $24 \mathrm{~h})$, respectively. Data, mean $\pm \operatorname{SD}(n=3)$. Columns showing non-overlapping lower-case letters indicate $p<0.05$ for multiple comparisons.

The annexin V/7AAD profiles for bladder cancer cells following NAC pre-incubation, WFA post-incubation, or both are demonstrated (Figure 3C). The bladder cancer J82 cells exposed for different incubation times of WFA induced more annexin V (+) cells than the control, which was inhibited by NAC pretreatment (Figure 3D).

\subsection{WFA Triggers Caspase-Related Signaling for Apoptosis in Bladder Cancer Cells}

The pancaspase profiles for bladder cancer cells following WFA incubation are shown (Figure 4A). The bladder cancer J82 cells exposed to different concentrations of WFA induced more pancaspase (+) cells than the control (Figure 4B).

The pancaspase profiles for bladder cancer cells following NAC pre-incubation, WFA post-incubation, or both are demonstrated (Figure 4C). The bladder cancer J82 cells exposed for different incubation times of WFA induced more pancaspase (+) cells than the control, which was inhibited by NAC pretreatment (Figure 4D).

Since the pancaspase is nonspecific to several caspase members, such as Cas- 1 and Cas-3 to -9 [21], it is important to clarify which caspases are involved in WFA-triggered apoptosis. WFA induced more c-PARP, c-Cas 9, c-Cas 8, and c-Cas 3 than the control, although the induction for c-Cas 8 was weak for bladder cancer cells (Figure 4E). The apoptosis signaling expression was suppressed by NAC and ZVAD pretreatment. 

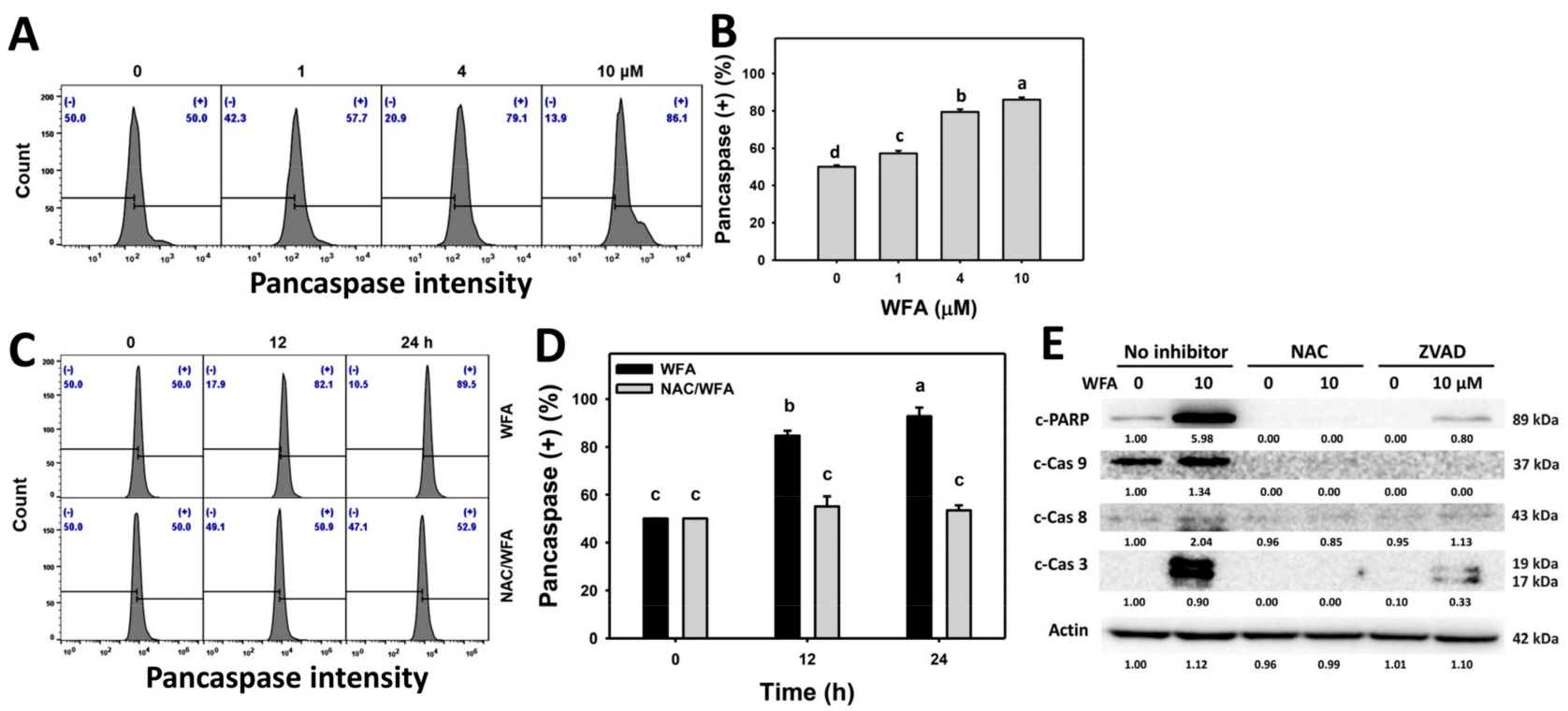

Figure 4. WFA activates caspases in bladder cancer cells. (A,B) Patterns and statistics for pancaspase change. Bladder cancer cells (J82) were treated with WFA $(24 \mathrm{~h}, 0$ to $10 \mu \mathrm{M})$, where the negative control for WFA $(0 \mu \mathrm{M})$ contained $0.1 \%$ DMSO. Symbol (+) indicates pancaspase (+). (C,D) Pattern and statistics for the NAC pretreated effect on pancaspase change of J82 cells following WFA incubation. Cells were pretreated and post treated with NAC $(8 \mathrm{mM}, 1 \mathrm{~h})$ and WFA $(0$ and $10 \mu \mathrm{M}$ for 12 and $24 \mathrm{~h})$, respectively. Data, mean $\pm \mathrm{SD}(n=3)$. Columns showing non-overlapping lower-case letters indicate $p<0.05$ for multiple comparisons. (E) Western blotting analysis for NAC or ZVAD pretreated effects on apoptosis signaling expression of J82 cells following WFA incubation. Cells were pretreated and post treated with NAC ( $8 \mathrm{mM}, 1 \mathrm{~h})$ or apoptosis inhibitor Z-VAD-FMK (ZVAD) $(20 \mu \mathrm{M}, 2 \mathrm{~h})$ and WFA ( 0 and $10 \mu \mathrm{M}$ for $24 \mathrm{~h})$, respectively, where the negative control for WFA $(0 \mu \mathrm{M})$ contained $0.1 \%$ DMSO.

\subsection{WFA Produces ROS and Superoxide Stresses in Bladder Cancer Cells}

The preventive effects of NAC against antiproliferation and apoptosis as described above indicate the involvement of oxidative stress. To validate these changes of oxidative stresses, ROS and MitoSOX contents following WFA treatment were examined. The ROS and MitoSOX profiles for bladder cancer cells following WFA incubation are shown (Figure 5A,E). The bladder cancer J82 cells exposed to different concentrations of WFA induced more ROS (+) and MitoSOX (+) cells than the control (Figure 5B,F).

The ROS and MitoSOX profiles for bladder cancer cells following NAC pre-incubation, WFA post-incubation, or both are shown (Figure 5C,G). The bladder cancer J82 cells exposed for different incubation times of WFA induced more ROS (+) and MitoSOX (+) cells than the control, which was inhibited by NAC pretreatment (Figure 5D,H). 


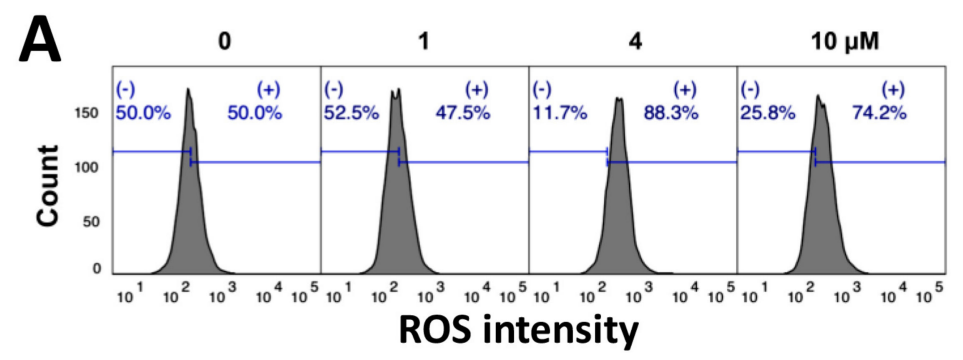

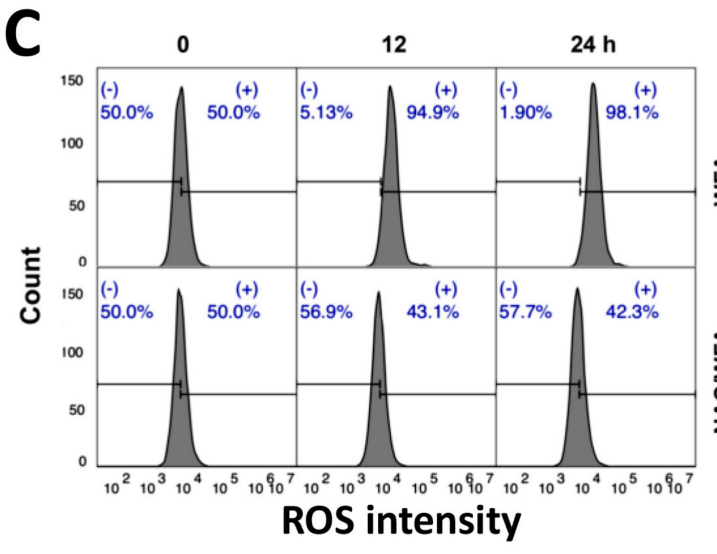

E

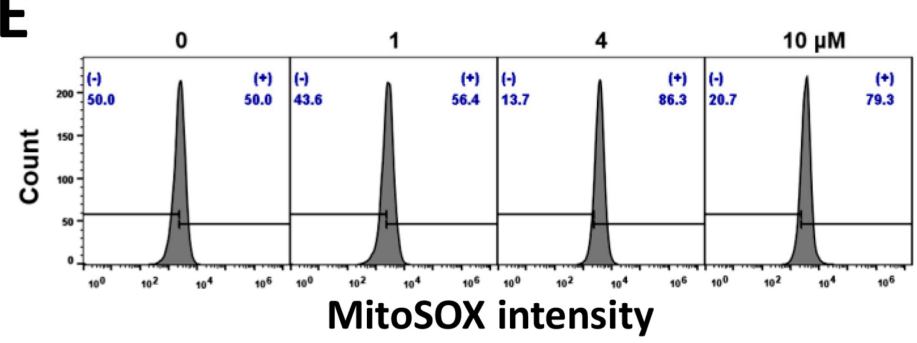

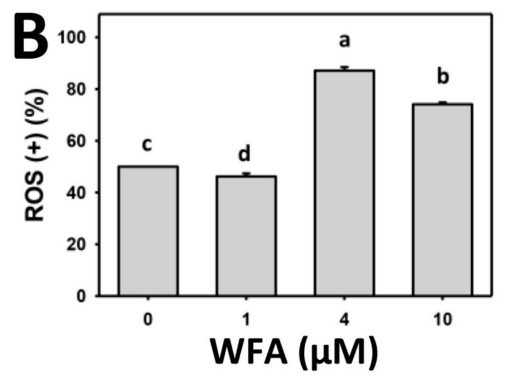

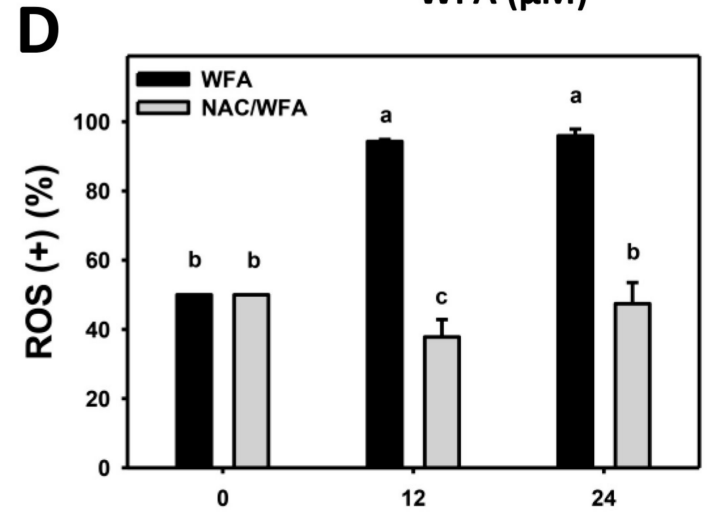

Time (h)

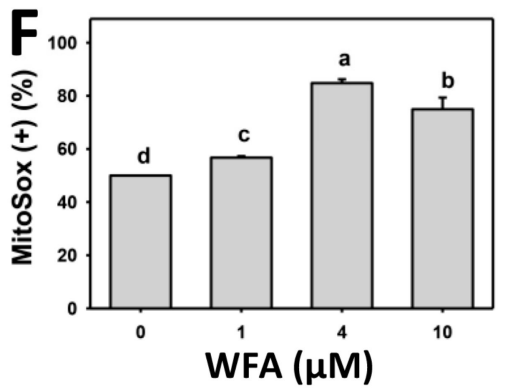

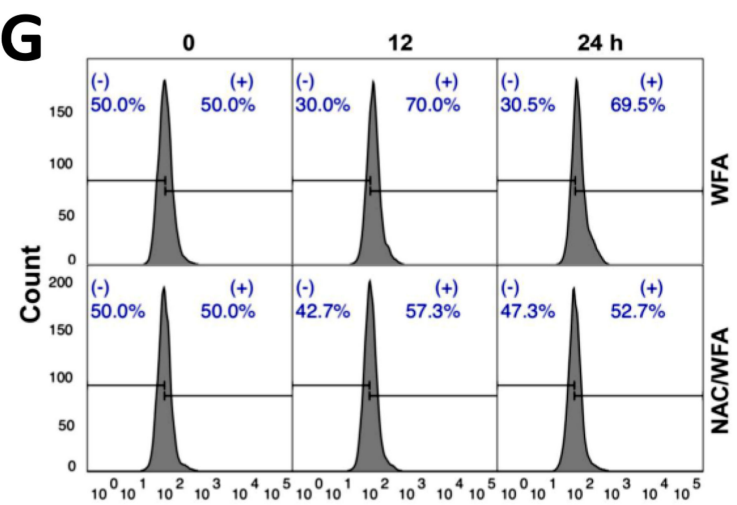

MitoSOX intensity
H

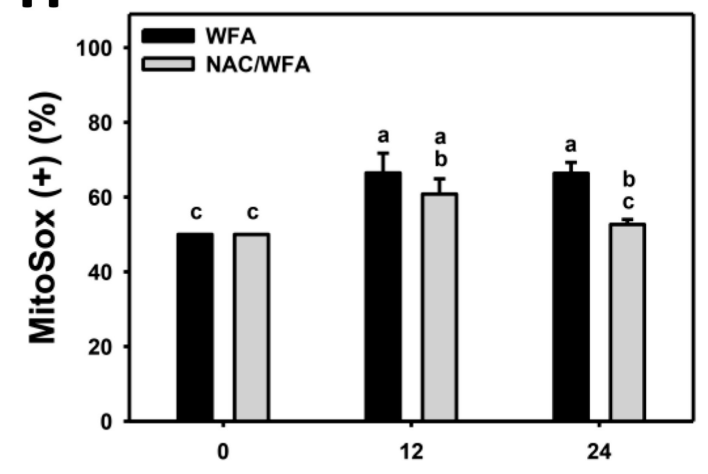

Time (h)

Figure 5. WFA induces ROS and MitoSOX generation in bladder cancer cells. (A,B,E,F) Patterns and statistics for ROS and MitoSOX changes. Bladder cancer cells (J82) were treated with WFA ( $24 \mathrm{~h}, 0$ to $10 \mu \mathrm{M}$ ), where the negative control for WFA $(0 \mu \mathrm{M})$ contained $0.1 \%$ DMSO. Symbol (+) indicates ROS or MitoSOX (+). (C,D,G,H) The pattern and statistics for NAC pretreated effect on ROS and MitoSOX expressions of J82 cells following WFA incubation. Cells were pretreated and post treated with NAC ( $8 \mathrm{mM}, 1 \mathrm{~h})$ and WFA $(0$ and $10 \mu \mathrm{M}$ for 12 and $24 \mathrm{~h})$, respectively. Data, mean $\pm \operatorname{SD}(n=3)$. Columns showing non-overlapping lower-case letters indicate $p<0.05$ for multiple comparisons. 


\subsection{WFA Triggers MMP Impairment in Bladder Cancer Cells}

MMP also contributes to drug-induced oxidative stress, and it is essential to examine MMP contents following WFA treatment. The MMP profiles for bladder cancer cells following WFA incubation are shown (Figure 6A). The bladder cancer J82 cells exposed to different concentrations of WFA induced more MMP (-) cells than the control (Figure 6B).
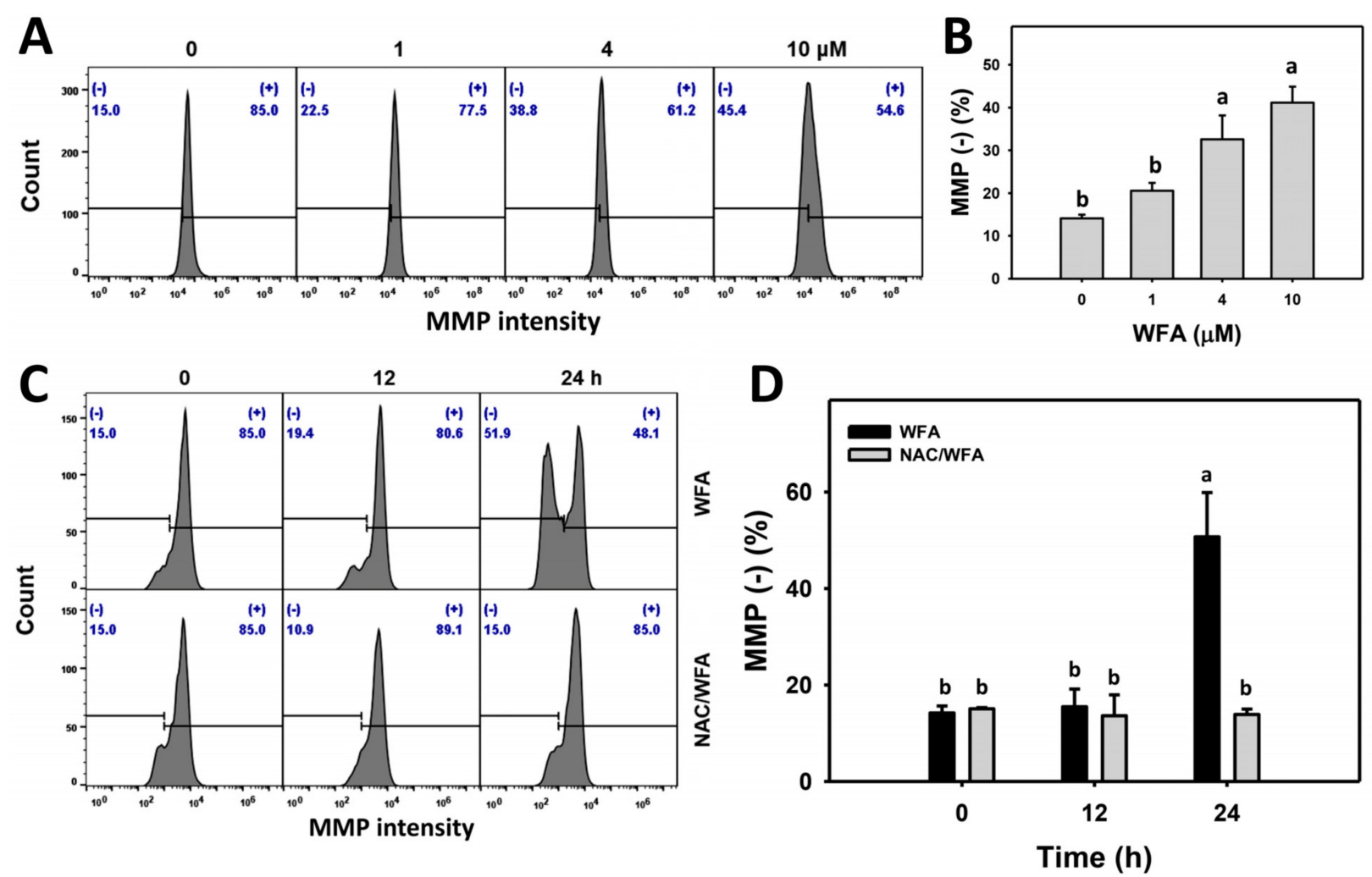

Figure 6. WFA induces MMP impairment in bladder cancer cells. (A,B) Patterns and statistics for MMP change. Bladder cancer cells (J82) were treated with WFA $(24 \mathrm{~h}, 0$ to $10 \mu \mathrm{M})$, where the negative control for WFA $(0 \mu \mathrm{M})$ contained $0.1 \%$ DMSO. Symbol (-) indicates MMP (-). (C,D) The pattern and statistics for the NAC pretreated effect on MMP expression of J82 cells following WFA incubation. Cells were pretreated and post treated with NAC ( $8 \mathrm{mM}, 1 \mathrm{~h})$ and WFA $(0$ and $10 \mu \mathrm{M}$ for 12 and $24 \mathrm{~h}$ ), respectively. Data, mean $\pm \mathrm{SD}(n=3)$. Columns showing non-overlapping lower-case letters indicate $p<0.05$ for multiple comparisons.

The MMP profiles for bladder cancer cells following NAC pre-incubation, WFA postincubation, or both are demonstrated (Figure 6C). The bladder cancer J82 cells exposed for different incubation times of WFA induced more MMP (-) cells than the control, which was inhibited by NAC pretreatment (Figure 6D).

\subsection{WFA Shows Dysregulated Antioxidant Signaling in Bladder Cancer Cells}

When drugs induce oxidative stress, the antioxidant gene expressions are altered [34,35]. Therefore, the involvement of the antioxidant signaling response in oxidative stress induction following WFA was further examined. WFA-induced mRNA expression for the NFE2L2, CAT, SOD1, TXN, GSR, NQO1, and HMOX1 genes compared to the control at particular time intervals is shown (Figure 7A). The bioinformatic analysis for proteinprotein interaction using STRING was conducted [36], indicating that these WFA affecting antioxidant signaling proteins are interconnected (Figure 7B). 


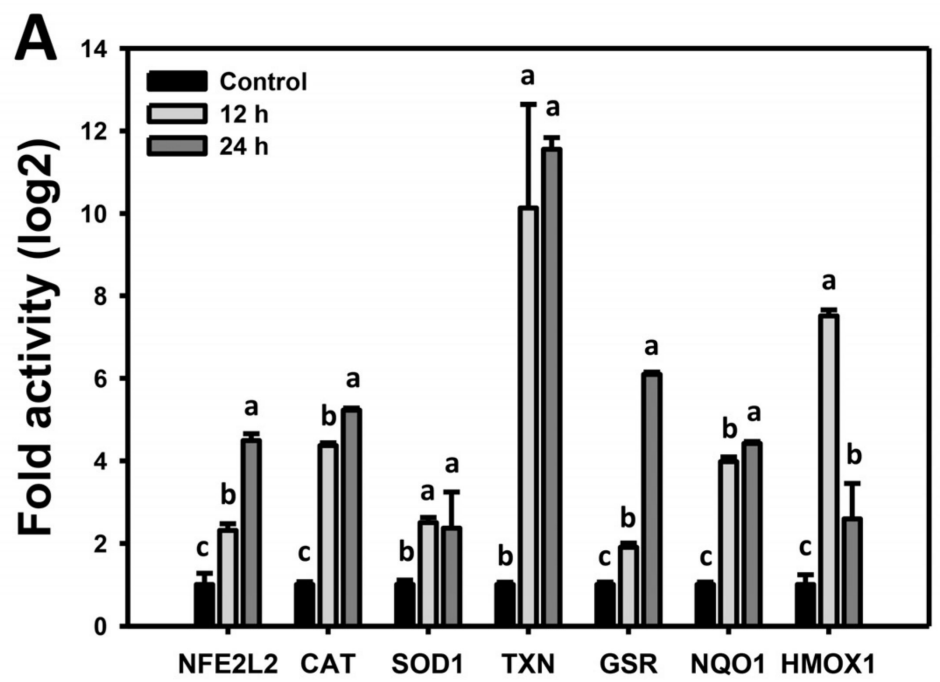

B

Figure 7. Gene expression and relationship between antioxidant signaling in WFA-treated bladder cancer cells. (A) Realtime PCR analysis. Cells were pretreated and post treated with NAC ( $8 \mathrm{mM}, 1 \mathrm{~h})$ and WFA $(0$ and $10 \mu \mathrm{M}$ for 12 and $24 \mathrm{~h}$ ), respectively. Subsequently, real-time PCR for mRNA expression in these drug-treated cells was performed. Data, mean $\pm \mathrm{SD}(n=3)$. Columns showing non-overlapping lower-case letters indicate $p<0.05$ for multiple comparisons.

(B) Bioinformatics analysis using STRING protein-protein interaction.

\subsection{WFA Triggers $\gamma H 2 A X$ and 8-OHdG DNA Damage in Bladder Cancer Cells}

$\gamma \mathrm{H} 2 \mathrm{AX}$ and 8-OHdG detection further evaluated the possibility that WFA induced oxidative stress, acting on DNA damage. The $\gamma \mathrm{H} 2 \mathrm{AX}$ and 8-OHdG profiles for bladder cancer cells following WFA incubation are shown (Figure 8A,E). The bladder cancer J82 cells exposed to different concentrations of WFA induced more $\gamma \mathrm{H} 2 \mathrm{AX}(+)$ and 8-OHdG $(+)$ cells than the control (Figure 8B,F).

The $\gamma \mathrm{H} 2 \mathrm{AX}$ and 8-OHdG profiles for bladder cancer cells following NAC pre-incubation, WFA post-incubation, or both are demonstrated (Figure $8 \mathrm{C}, \mathrm{G}$ ). The bladder cancer J82 cells exposed for different incubation times of WFA induced more $\gamma \mathrm{H} 2 \mathrm{AX}(+)$ and 8-OHdG (+) cells than the control. This process was inhibited by NAC pretreatment (Figure $8 \mathrm{D}, \mathrm{H}$ ). 

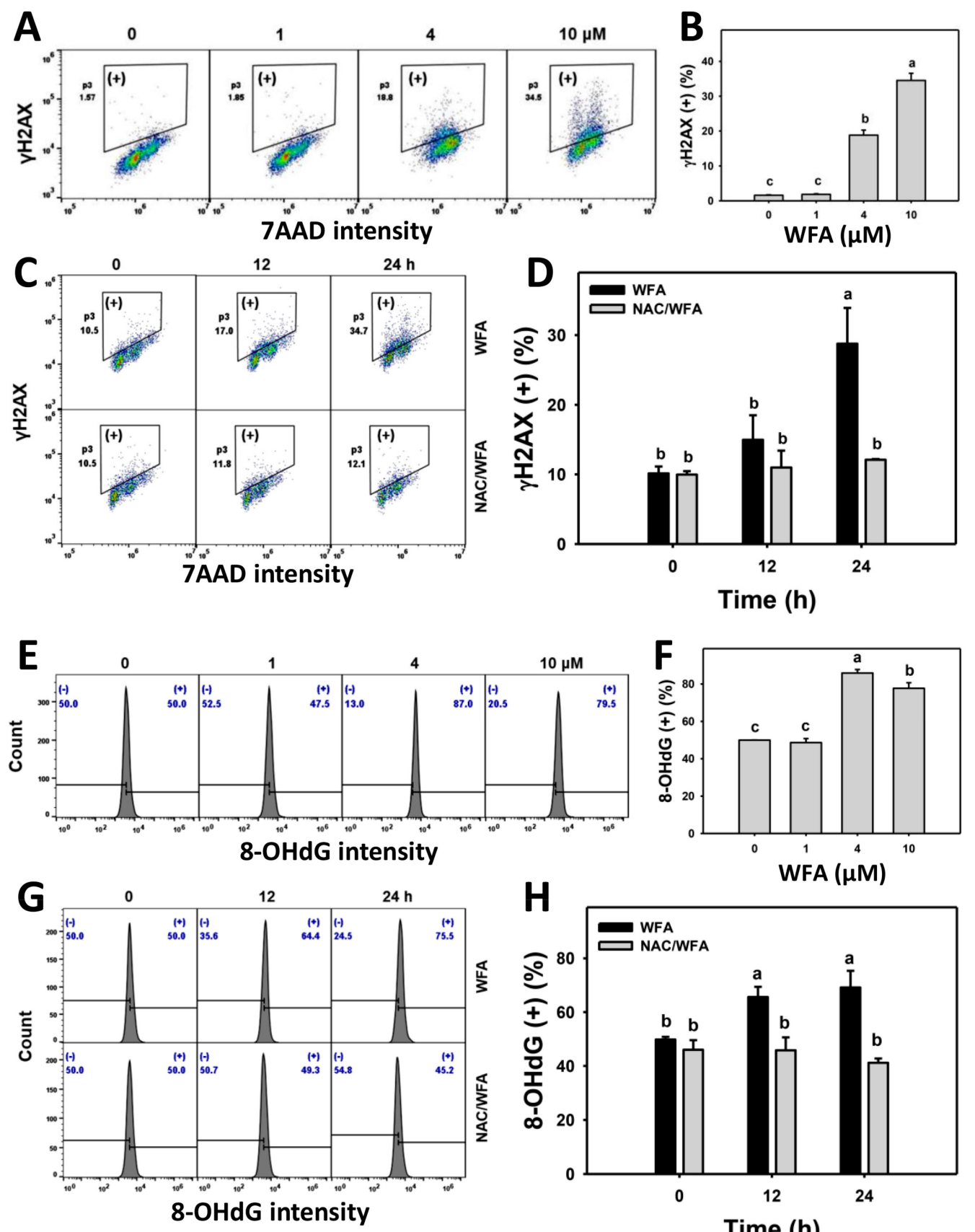

Time (h)

Figure 8. WFA induces DNA damage in bladder cancer cells. (A,B,E,F) Patterns and statistics for $\gamma \mathrm{H} 2 \mathrm{AX}$ and 8 -OHdG changes. Bladder cancer cells (J82) were treated with WFA $(24 \mathrm{~h}, 0$ to $10 \mu \mathrm{M})$, where the negative control for WFA $(0 \mu \mathrm{M})$ contained $0.1 \%$ DMSO. Symbol (+) indicates $\gamma \mathrm{H} 2 \mathrm{AX}$ or $8-\mathrm{OHdG}(+) .(\mathbf{C}, \mathbf{D}, \mathbf{G}, \mathbf{H})$ Pattern and statistics for the NAC pretreated effect on the $\gamma \mathrm{H} 2 \mathrm{AX}$ and 8-OHdG expression of J82 cells following WFA incubation. Cells were pretreated and post treated with NAC ( $8 \mathrm{mM}, 1 \mathrm{~h})$ and WFA ( 0 and $10 \mu \mathrm{M}$ for 12 and $24 \mathrm{~h})$, respectively. Data, mean $\pm \mathrm{SD}(n=3)$. Columns showing non-overlapping lower-case letters indicate $p<0.05$ for multiple comparisons.

\section{Discussion}

WFA has reported anticancer effects on several cancer cells, but it has rarely been investigated in bladder cancer cells. The current study confirms the anticancer effect of WFA in bladder cancer cells and explores the oxidative stress mechanisms involving cell cycle arrest, apoptosis, and DNA damage. 


\subsection{WFA Shows Differential Sensitivity to Cancer Cells}

Several cancer cell lines exhibit different responses to WFA. The $\mathrm{IC}_{50}$ values of WFA were reported in several cancer cells, e.g., 2-3 $\mu \mathrm{M}$ (24 h MTS assay), 0.2-1.2 $\mu \mathrm{M}$ ( $24 \mathrm{~h}$ MTT assay), 1.4-9.1 $\mu \mathrm{M}$ (24 h MTT assay), $2 \mu \mathrm{M}$ (48 h MTS assay), 0.5-1.5 $\mu \mathrm{M}$ (48 h sulforhodamine B assay), and 1-2 $\mu \mathrm{M}$ (48 h Alamar Blue assay) for oral [12], cervical [13], glioblastoma [14], pancreatic [15], lung [16], and melanoma [17] types. Under the same concentration ranges of WFA to cancer cell lines, the cell viability for normal human oral fibroblasts HGF-1 [12] and normal human lung fibroblasts MRC-5 and WI-38 [17] is higher than in cancer cells. Moreover, WFA has shown good drug safety in phase I and II clinical trials for advanced-stage osteosarcoma patients [37]. In the present study, the WFA in bladder cancer J82 cells showed an $\mathrm{IC}_{50}$ value of $3.1 \mu \mathrm{M}$ after a $24 \mathrm{~h}$ MTS assay. Therefore, we firstly demonstrate that WFA has an antiproliferative effect on bladder cancer cells. Although WFA shows drug safety to some non-bladder normal cell lines and patients for clinical trials as mentioned above $[12,17]$, a limitation of the present study is the experiment design lacking a non-cancer bladder cell line as a control. The selectivity of WFA in bladder cancer treatment warrants detailed investigations in the future.

\subsection{WFA Generates Oxidative Stress on Bladder Cancer Cells}

Anticancer drugs may inhibit proliferation through comprehensive oxidative stress induction. For example, a natural marine product manoalide induces cellular and mitochondrial oxidative stress in oral cancer cells [38]. Similarly, WFA generates ROS and MitoSOX in colon, oral, and breast cancer cells $[12,39,40]$. In addition to ROS and MitoSOX, WFA induces MMP impairment in bladder cancer cells (Figures 5 and 6), indicating that this oxidative stress-inducing ability of WFA is also available to bladder cancer cells.

Mitochondria are the central system for oxidative stress generation. When mitochondria are dysfunctional, the gene expression for antioxidant genes is altered [41]. When oxidative stress dramatically accumulates, RELA activates enzymatic antioxidants, such as CAT [34]. HMOX1 and SOD1 mRNA is overexpressed in response to UVC/Nepenthes extract-induced ROS generation [35]. GSR mRNA expression is upregulated by physapruin A-induced ROS generation in breast cancer cells [42]. High oxidative stress in cultured oocytes results in overexpression of mRNA for CAT, SOD1, SOD2, and GSR antioxidant genes [43]. Similarly, mRNA and protein levels for $C A T, S O D 1$, and HMOX1 genes were activated in UVC-irradiated mice [44]. UVC was also reported to induce ROS generation in oral cancer cells [35,45]. Oxidative stress also activates TXN, which is a target of NFE2L2 [46]. NQO1 knockdown inhibits ROS generation in prostate cancer cells [47]; therefore, NQO1 upregulation may be associated with ROS induction.

Similarly, WFA upregulates the mRNA expression of antioxidant genes (NFE2L2, CAT, SOD1, TXN, GSR, NQO1, and HMOX1) (Figure 7) in bladder cancer cells associated with oxidative stress generation (Figures 5 and 6). Therefore, these results suggest that this antioxidant mRNA expression is upregulated in response to WFA-generated oxidative stress. Still, mRNA expression fails to overcome the high level of oxidative stress.

There are three SOD isoforms, including cytoplasmic (SOD1), mitochondrial (SOD2), and extracellular (SOD3) types, in mammals [48]. The SOD1 mRNA was activated; however, the expression of SOD2 and SOD3 genes was not examined in the present study. Since WFA induces MitoSOX generation in oral cancer cells, mitochondrial SOD2 expression may play a vital role in WFA-induced oxidative stress.

Moreover, WFA-activated antioxidant signaling by upregulating mRNA expression lacks protein-level confirmation for antioxidant genes. Therefore, it warrants detailed investigations of both the mRNA and protein expression of all SOD isoforms in WFAtreated oral cancer cells in the future to provide a comprehensive view of the mechanisms of action of WFA-induced oxidative stress.

Both cellular and mitochondrial oxidative stress has been demonstrated to trigger apoptosis in the present study. Lipid peroxidation was also reported as a proapoptotic factor [49]. However, the role of lipid peroxidation was not examined. Selective anticancer 
cytotoxicity may be caused by lipid peroxidation [50]. Further, 4-hydroxynonenal (4HNE) [51,52] or 4-hydroxy-2-nonenal (HNE) [53] is an $\alpha, \beta$-unsaturated hydroxyalkenal generated by lipid peroxidation. For example, polyunsaturated fatty acids (PUFA) can generate the peroxidation product $\mathrm{HNE}$ or 4-HNE, which is known to act as a second messenger of ROS [52,54], the signaling molecule regulating cell growth. The potential anticancer effects of HNE can be attenuated by GSH and NAC [55]. It warrants further detailed investigation that explores the role of lipid peroxidation in WFA-induced oxidative stress and apoptosis as well as selective killing of bladder cancer cells.

\subsection{WFA Drives Apoptosis and Causes DNA Damage of Bladder Cancer Cells}

Oxidative stress-regulating drugs may modulate the effects of apoptosis or DNA damage for antiproliferation of cancer cells [6]. A number of reports indicate that WFA triggers apoptosis in several types of cancer cells $[14,17,56,57]$. WFA induces more intrinsic apoptotic c-Cas 9 expression in glioblastoma cell studies than extrinsic apoptotic c-Cas 8 expression [14], which has the same tendency for bladder cancer cells (Figure 4). In the oral cancer cell study, c-Cas 8 and c-Cas 9 were induced in the WFA concentration at $60 \%$ and $70 \%$ viability but declined at a concentration of $50 \%$ viability [12]. Therefore, the induction of intrinsic and extrinsic apoptosis signaling may depend on the context of cancer cell types.

Except for oral [12] and breast [58] cancer cells, the finding that WFA induces DNA damage is rarely reported in other cancer cells. WFA overexpresses $\gamma \mathrm{H} 2 \mathrm{AX}$ in breast [58], oral [12], and bladder (Figure 8) cancer cells. Moreover, WFA-induced oxidative stress further attacks DNA to generate oxidative DNA damage, as shown in oral [12] and bladder (Figure 8) cancer cells.

\subsection{WFA Blocks G2/M Progression on Bladder Cancer Cells}

WFA arrests G2/M progression in several types of cancer cells, such as gastric [59], osteosarcoma [60], leukemia [61], breast [62], oral [12], colon [39], and glioblastoma [14] cancer cells. Furthermore, prostate cancer cells following WFA treatment induce a mitotic catastrophe [63]. Consistently, WFA shows higher G2/M populations in bladder cancer cells (Figure 2).

\subsection{NAC Suppresses Antiproliferation Mechanisms of WFA on Bladder Cancer Cells}

The ROS inhibitor (NAC) pretreatment confirmed the function of oxidative stress in several WFA anticancer cell studies. For example, NAC suppresses WFA-induced apoptosis in head and neck cancer AMC-HN4 cells [64]. In addition, NAC alleviates WFA-mediated endoplasmic reticulum stress and apoptosis in renal cancer cells [65]. NAC also suppresses ROS generation, MMP destruction, and apoptosis in colon cancer cells [39]. Similarly, NAC suppresses WFA-induced changes in bladder cancer cells, including antiproliferation, G2/M arrest, apoptosis expression for annexin V, pancaspase function, caspase signaling protein expression, ROS induction, MMP destruction, double-strand breaks, and oxidative DNA damage. These findings suggest that oxidative stress regulates the antiproliferation effect and mechanism in bladder cancer cells following WFA treatment. The NAC effect on the mRNA and protein expression for antioxidant signaling was not examined in the present study. Thus, the relationship between antioxidant signaling and oxidative stress is still unclear. More detailed investigations of NAC pretreatment effects on antioxidant signaling are warranted in the future.

\subsection{Potential Targets of WFA}

Heat shock protein 90 (HSP90) [66] and annexin II [67] were reported as additional targets of WFA. For example, WFA binds to HSP90 to inhibit HSP90 chaperone activity [66] and reduces the interaction between the FA complementation group A (FANCA) and HSP90 to reduce the single-strand annealing sub-pathway (SSA) repair, leading to doublestrand break (DSB) accumulation [68] and apoptosis. This finding can support our results 
that WFA induces DSB and apoptosis. Moreover, WFA is reported to covalently bind to annexin II to change the cytoskeleton network and inhibit cancer cell migration and invasion [67], which was not addressed in the present study.

\section{Conclusions}

The antiproliferation effect of WFA treatment on bladder cancer cells has been little studied as yet. Here, we provided the first evidence that WFA exhibits an antiproliferationmodulating impact on bladder cancer cells in an oxidative stress-dependent manner. Antiproliferation generally increased with WFA doses and exposure time. Mechanistically, WFA generates cellular and mitochondrial oxidative stresses with the destruction of bladder cancer cells caused by the increase of ROS/MitoSOX and the decrease of MMP. Furthermore, WFA-induced oxidative stress was associated with the upregulation of antioxidant signaling expressions. Moreover, NAC pretreatment reverted oxidative stresses and their associated responses to G2/M arrest, apoptosis, and DNA damage in bladder cancer cells. Therefore, WFA causes oxidative stress-dependent antiproliferation and apoptosis effects in bladder cancer cells.

Author Contributions: Conceptualization, T.-M.C., W.-J.W., and H.-W.C.; data curation, K.-H.W., Y.-T.C. and Y.-C.Y.; formal analysis, K.-H.W. and Y.-T.C.; methodology, T.-M.C., H.-R.W., B.-W.Y., C.-H.Y., and T.-J.Y.; supervision, W.-J.W. and H.-W.C.; writing-original draft, T.-M.C. and H.-W.C.; writing - review and editing, W.-J.W. and H.-W.C. All authors have read and agreed to the published version of the manuscript.

Funding: This work was partly supported by funds of the Ministry of Science and Technology (MOST 109-2314-B-037-093; MOST 107-2314-B-037-077-MY3; MOST 108-2320-B-037-015-MY3), the National Sun Yat-sen University-KMU Joint Research Project (\#NSYSUKMU 110-P016), the Kaohsiung Medical University Hospital (KMUH-109-9R58; KMUH106-6R54; KMUH108-8R56), and the Kaohsiung Medical University Research Center (KMU-TC108A04).

Institutional Review Board Statement: Not applicable

Informed Consent Statement: Not applicable

Data Availability Statement: Data is contained within the article.

Acknowledgments: The authors thank our colleague Hans-Uwe Dahms for editing the manuscript.

Conflicts of Interest: The authors declare that there are no conflicts of interest among them.

\section{References}

1. Bray, F.; Ferlay, J.; Soerjomataram, I.; Siegel, R.L.; Torre, L.A.; Jemal, A. Global cancer statistics 2018: GLOBOCAN estimates of incidence and mortality worldwide for 36 cancers in 185 countries. CA Cancer J. Clin. 2018, 68, 394-424. [CrossRef] [PubMed]

2. Ferlay, J.; Colombet, M.; Soerjomataram, I.; Mathers, C.; Parkin, D.M.; Pineros, M.; Znaor, A.; Bray, F. Estimating the global cancer incidence and mortality in 2018: GLOBOCAN sources and methods. Int. J. Cancer 2019, 144, 1941-1953. [CrossRef]

3. Acharya, A.; Das, I.; Chandhok, D.; Saha, T. Redox regulation in cancer: A double-edged sword with therapeutic potential. Oxid. Med. Cell Longev. 2010, 3, 23-34. [CrossRef] [PubMed]

4. Chiu, C.C.; Huang, J.W.; Chang, F.R.; Huang, K.J.; Huang, H.M.; Huang, H.W.; Chou, C.K.; Wu, Y.C.; Chang, H.W. Golden berry-derived 4beta-hydroxywithanolide $\mathrm{E}$ for selectively killing oral cancer cells by generating ROS, DNA damage, and apoptotic pathways. PLoS ONE 2013, 8, e64739. [CrossRef] [PubMed]

5. Lee, J.C.; Hou, M.F.; Huang, H.W.; Chang, F.R.; Yeh, C.C.; Tang, J.Y.; Chang, H.W. Marine algal natural products with antioxidative, anti-inflammatory, and anti-cancer properties. Cancer Cell Int. 2013, 13, 55. [CrossRef] [PubMed]

6. Tang, J.Y.; Ou-Yang, F.; Hou, M.F.; Huang, H.W.; Wang, H.R.; Li, K.T.; Fayyaz, S.; Shu, C.W.; Chang, H.W. Oxidative stressmodulating drugs have preferential anticancer effects-Involving the regulation of apoptosis, DNA damage, endoplasmic reticulum stress, autophagy, metabolism, and migration. Semin. Cancer Biol. 2019, 58, 109-117. [CrossRef]

7. Gorrini, C.; Harris, I.S.; Mak, T.W. Modulation of oxidative stress as an anticancer strategy. Nat. Rev. Drug Discov. 2013, 12, 931-947. [CrossRef]

8. Kim, S.J.; Kim, H.S.; Seo, Y.R. Understanding of ROS-inducing strategy in anticancer therapy. Oxid. Med. Cell Longev. 2019, 2019, 5381692. [CrossRef] 
9. Wadhwa, R.; Yadav, N.S.; Katiyar, S.P.; Yaguchi, T.; Lee, C.; Ahn, H.; Yun, C.O.; Kaul, S.C.; Sundar, D. Molecular dynamics simulations and experimental studies reveal differential permeability of withaferin-A and withanone across the model cell membrane. Sci. Rep. 2021, 11, 2352. [CrossRef]

10. Batumalaie, K.; Amin, M.A.; Murugan, D.D.; Sattar, M.Z.; Abdullah, N.A. Withaferin A protects against palmitic acid-induced endothelial insulin resistance and dysfunction through suppression of oxidative stress and inflammation. Sci. Rep. 2016, 6, 27236. [CrossRef]

11. Malik, F.; Kumar, A.; Bhushan, S.; Khan, S.; Bhatia, A.; Suri, K.A.; Qazi, G.N.; Singh, J. Reactive oxygen species generation and mitochondrial dysfunction in the apoptotic cell death of human myeloid leukemia HL-60 cells by a dietary compound withaferin A with concomitant protection by N-acetyl cysteine. Apoptosis 2007, 12, 2115-2133. [CrossRef] [PubMed]

12. Chang, H.W.; Li, R.N.; Wang, H.R.; Liu, J.R.; Tang, J.Y.; Huang, H.W.; Chan, Y.H.; Yen, C.Y. Withaferin A induces oxidative stress-mediated apoptosis and DNA damage in oral cancer cells. Front. Physiol. 2017, 8, 634. [CrossRef]

13. Munagala, R.; Kausar, H.; Munjal, C.; Gupta, R.C. Withaferin A induces p53-dependent apoptosis by repression of HPV oncogenes and upregulation of tumor suppressor proteins in human cervical cancer cells. Carcinogenesis 2011, 32, 1697-1705. [CrossRef] [PubMed]

14. Tang, Q.; Ren, L.; Liu, J.; Li, W.; Zheng, X.; Wang, J.; Du, G. Withaferin A triggers G2/M arrest and intrinsic apoptosis in glioblastoma cells via ATF4-ATF3-CHOP axis. Cell Prolif. 2019, 53, e12706. [CrossRef] [PubMed]

15. Li, X.; Zhu, F.; Jiang, J.; Sun, C.; Wang, X.; Shen, M.; Tian, R.; Shi, C.; Xu, M.; Peng, F.; et al. Synergistic antitumor activity of withaferin A combined with oxaliplatin triggers reactive oxygen species-mediated inactivation of the PI3K/AKT pathway in human pancreatic cancer cells. Cancer Lett. 2015, 357, 219-230. [CrossRef]

16. Hsu, J.H.; Chang, P.M.; Cheng, T.S.; Kuo, Y.L.; Wu, A.T.; Tran, T.H.; Yang, Y.H.; Chen, J.M.; Tsai, Y.C.; Chu, Y.S.; et al. Identification of withaferin A as a potential candidate for anti-cancer therapy in non-small cell lung cancer. Cancers 2019, 11, 1003. [CrossRef]

17. Nagy, Z.; Cheung, B.B.; Tsang, W.; Tan, O.; Herath, M.; Ciampa, O.C.; Shadma, F.; Carter, D.R.; Marshall, G.M. Withaferin A activates TRIM16 for its anti-cancer activity in melanoma. Sci. Rep. 2020, 10, 19724. [CrossRef]

18. Liu, X.; Chen, L.; Liang, T.; Tian, X.D.; Liu, Y.; Zhang, T. Withaferin A induces mitochondrial-dependent apoptosis in non-small cell lung cancer cells via generation of reactive oxygen species. J. BUON 2017, 22, 244-250.

19. Li, A.X.; Sun, M.; Li, X. Withaferin-A induces apoptosis in osteosarcoma U2OS cell line via generation of ROS and disruption of mitochondrial membrane potential. Eur. Rev. Med. Pharmacol. Sci. 2017, 21, 1368-1374.

20. Chen, C.Y.; Yen, C.Y.; Wang, H.R.; Yang, H.P.; Tang, J.Y.; Huang, H.W.; Hsu, S.H.; Chang, H.W. Tenuifolide B from Cinnamomum tenuifolium stem selectively inhibits proliferation of oral cancer cells via apoptosis, ROS generation, mitochondrial depolarization, and DNA damage. Toxins 2016, 8, 319. [CrossRef]

21. Yeh, C.C.; Tseng, C.N.; Yang, J.I.; Huang, H.W.; Fang, Y.; Tang, J.Y.; Chang, F.R.; Chang, H.W. Antiproliferation and induction of apoptosis in Ca9-22 oral cancer cells by ethanolic extract of Gracilaria tenuistipitata. Molecules 2012, 17, 10916-10927. [CrossRef] [PubMed]

22. Vignon, C.; Debeissat, C.; Georget, M.T.; Bouscary, D.; Gyan, E.; Rosset, P.; Herault, O. Flow cytometric quantification of all phases of the cell cycle and apoptosis in a two-color fluorescence plot. PLoS ONE 2013, 8, e68425. [CrossRef] [PubMed]

23. Huang, H.W.; Tang, J.Y.; Ou-Yang, F.; Wang, H.R.; Guan, P.Y.; Huang, C.Y.; Chen, C.Y.; Hou, M.F.; Sheu, J.H.; Chang, H.W. Sinularin selectively kills breast cancer cells showing G2/M arrest, apoptosis, and oxidative DNA damage. Molecules 2018, $23,849$. [CrossRef] [PubMed]

24. Yeh, C.C.; Yang, J.I.; Lee, J.C.; Tseng, C.N.; Chan, Y.C.; Hseu, Y.C.; Tang, J.Y.; Chuang, L.Y.; Huang, H.W.; Chang, F.R.; et al. Anti-proliferative effect of methanolic extract of Gracilaria tenuistipitata on oral cancer cells involves apoptosis, DNA damage, and oxidative stress. BMC Complement. Altern. Med. 2012, 12, 142. [CrossRef] [PubMed]

25. Chang, Y.T.; Huang, C.Y.; Tang, J.Y.; Liaw, C.C.; Li, R.N.; Liu, J.R.; Sheu, J.H.; Chang, H.W. Reactive oxygen species mediate soft corals-derived sinuleptolide-induced antiproliferation and DNA damage in oral cancer cells. Onco Targets Ther. 2017, 10, 3289-3297. [CrossRef]

26. Chang, H.S.; Tang, J.Y.; Yen, C.Y.; Huang, H.W.; Wu, C.Y.; Chung, Y.A.; Wang, H.R.; Chen, I.S.; Huang, M.Y.; Chang, H.W. Antiproliferation of Cryptocarya concinna-derived cryptocaryone against oral cancer cells involving apoptosis, oxidative stress, and DNA damage. BMC Complement. Altern. Med. 2016, 16, 94. [CrossRef]

27. Chang, H.W.; Yen, C.Y.; Chen, C.H.; Tsai, J.H.; Tang, J.Y.; Chang, Y.T.; Kao, Y.H.; Wang, Y.Y.; Yuan, S.F.; Lee, S.Y. Evaluation of the mRNA expression levels of integrins alpha3, alpha5, beta1 and beta6 as tumor biomarkers of oral squamous cell carcinoma. Oncol. Lett. 2018, 16, 4773-4781.

28. Yen, C.Y.; Huang, C.Y.; Hou, M.F.; Yang, Y.H.; Chang, C.H.; Huang, H.W.; Chen, C.H.; Chang, H.W. Evaluating the performance of fibronectin 1 (FN1), integrin alpha4beta1 (ITGA4), syndecan-2 (SDC2), and glycoprotein CD44 as the potential biomarkers of oral squamous cell carcinoma (OSCC). Biomarkers 2013, 18, 63-72. [CrossRef]

29. Stagos, D.; Balabanos, D.; Savva, S.; Skaperda, Z.; Priftis, A.; Kerasioti, E.; Mikropoulou, E.V.; Vougogiannopoulou, K.; Mitakou, S.; Halabalaki, M.; et al. Extracts from the mediterranean food plants Carthamus lanatus, Cichorium intybus, and Cichorium spinosum enhanced GSH levels and increased Nrf2 expression in human endothelial cells. Oxid. Med. Cell Longev. 2018, $2018,6594101$. [CrossRef] 
30. Liu, P.F.; Farooqi, A.A.; Peng, S.Y.; Yu, T.J.; Dahms, H.U.; Lee, C.H.; Tang, J.Y.; Wang, S.C.; Shu, C.W.; Chang, H.W. Regulatory effects of noncoding RNAs on the interplay of oxidative stress and autophagy in cancer malignancy and therapy. Semin. Cancer Biol. 2020. [CrossRef]

31. Yu, T.J.; Tang, J.Y.; Ou-Yang, F.; Wang, Y.Y.; Yuan, S.F.; Tseng, K.; Lin, L.C.; Chang, H.W. Low concentration of withaferin A inhibits oxidative stress-mediated migration and invasion in oral cancer cells. Biomolecules 2020, 10, 777. [CrossRef]

32. Livak, K.J.; Schmittgen, T.D. Analysis of relative gene expression data using real-time quantitative PCR and the 2(-Delta Delta C(T)) Method. Methods 2001, 25, 402-408. [CrossRef] [PubMed]

33. Peng, S.Y.; Wang, Y.Y.; Lan, T.H.; Lin, L.C.; Yuan, S.F.; Tang, J.Y.; Chang, H.W. Low dose combined treatment with ultraviolet-C and withaferin a enhances selective killing of oral cancer cells. Antioxidants 2020, 9, 1120. [CrossRef]

34. Wang, Y.; Qi, H.; Liu, Y.; Duan, C.; Liu, X.; Xia, T.; Chen, D.; Piao, H.L.; Liu, H.X. The double-edged roles of ROS in cancer prevention and therapy. Theranostics 2021, 11, 4839-4857. [CrossRef]

35. Peng, S.Y.; Lin, L.C.; Yang, Z.W.; Chang, F.R.; Cheng, Y.B.; Tang, J.Y.; Chang, H.W. Combined treatment with low cytotoxic ethyl acetate Nepenthes extract and ultraviolet-C improves antiproliferation to oral cancer cells via oxidative stress. Antioxidants $\mathbf{2 0 2 0}$ 9, 876. [CrossRef]

36. Szklarczyk, D.; Gable, A.L.; Lyon, D.; Junge, A.; Wyder, S.; Huerta-Cepas, J.; Simonovic, M.; Doncheva, N.T.; Morris, J.H.; Bork, P.; et al. STRING v11: Protein-protein association networks with increased coverage, supporting functional discovery in genome-wide experimental datasets. Nucleic Acids Res. 2019, 47, D607-D613. [CrossRef]

37. Pires, N.; Gota, V.; Gulia, A.; Hingorani, L.; Agarwal, M.; Puri, A. Safety and pharmacokinetics of Withaferin-A in advanced stage high grade osteosarcoma: A phase I trial. J. Ayurveda Integr. Med. 2020, 11, 68-72. [CrossRef] [PubMed]

38. Wang, H.R.; Chen, P.H.; Tang, J.Y.; Yen, C.Y.; Su, Y.C.; Huang, M.Y.; Chang, H.W. Manoalide shows mutual interaction between cellular and mitochondrial reactive species with apoptosis in oral cancer cells. Oxid. Med. Cell Longev. 2021, 2021, 6667355. [CrossRef] [PubMed]

39. Xia, S.; Miao, Y.; Liu, S. Withaferin A induces apoptosis by ROS-dependent mitochondrial dysfunction in human colorectal cancer cells. Biochem. Biophys. Res. Commun. 2018, 503, 2363-2369. [CrossRef]

40. Hahm, E.R.; Moura, M.B.; Kelley, E.E.; Van Houten, B.; Shiva, S.; Singh, S.V. Withaferin A-induced apoptosis in human breast cancer cells is mediated by reactive oxygen species. PLOS ONE 2011, 6, e23354. [CrossRef]

41. Singh, K.K. Mitochondria damage checkpoint in apoptosis and genome stability. FEMS Yeast Res. 2004, 5, 127-132. [CrossRef] [PubMed]

42. Yu, T.-J.; Cheng, Y.-B.; Lin, L.-C.; Tsai, Y.-H.; Yao, B.-Y.; Tang, J.-Y.; Chang, F.-R.; Yen, C.-H.; Ou-Yang, F.; Chang, H.-W. Physalis peruviana-derived physapruin A (PHA) inhibits breast cancer cell proliferation and induces oxidative-stress-mediated apoptosis and DNA damage. Antioxidants 2021, 10, 393. [CrossRef]

43. Salavati, M.; Ghafari, F.; Zhang, T.; Fouladi-Nashta, A.A. Effects of oxygen concentration on in vitro maturation of canine oocytes in a chemically defined serum-free medium. Reproduction 2012, 144, 547-556. [CrossRef]

44. Nishijima, Y.; Ibuki, A.; Minematsu, T.; Sanada, H. Expression profiles of the antioxidant enzymes gene (SOD1, CAT, GPX, and HMOX1) in the skin of UV-irradiated and obese mice. J. Nurs. Sci. Eng. 2016, 3, 13-20.

45. Peng, S.Y.; Tang, J.Y.; Li, R.N.; Huang, H.W.; Wu, C.Y.; Chiu, C.C.; Chang, F.R.; Zhang, H.W.; Lee, Y.J.; Sheu, J.H.; et al. Oxidative stress-dependent synergistic antiproliferation, apoptosis, and DNA damage of ultraviolet-C and coral-derived sinularin combined treatment for oral cancer cells. Cancers 2021, 13, 2450. [CrossRef]

46. Rostila, A.M.; Anttila, S.L.; Lalowski, M.M.; Vuopala, K.S.; Toljamo, T.I.; Lindstrom, I.; Baumann, M.H.; Puustinen, A.M. Reactive oxygen species-regulating proteins peroxiredoxin 2 and thioredoxin, and glyceraldehyde-3-phosphate dehydrogenase are differentially abundant in induced sputum from smokers with lung cancer or asbestos exposure. Eur. J. Cancer Prev. 2020, 29, 238-247. [CrossRef]

47. Thapa, D.; Meng, P.; Bedolla, R.G.; Reddick, R.L.; Kumar, A.P.; Ghosh, R. NQO1 suppresses NF-kappaB-p300 interaction to regulate inflammatory mediators associated with prostate tumorigenesis. Cancer Res. 2014, 74, 5644-5655. [CrossRef] [PubMed]

48. Zelko, I.N.; Mariani, T.J.; Folz, R.J. Superoxide dismutase multigene family: A comparison of the CuZn-SOD (SOD1), Mn-SOD (SOD2), and EC-SOD (SOD3) gene structures, evolution, and expression. Free Radic. Biol. Med. 2002, 33, 337-349. [CrossRef]

49. Wojcik, P.; Zarkovic, N.; Gegotek, A.; Skrzydlewska, E. Involvement of metabolic lipid mediators in the regulation of apoptosis. Biomolecules 2020, 10, 402. [CrossRef]

50. Sroda-Pomianek, K.; Michalak, K.; Swiatek, P.; Pola, A.; Palko-Labuz, A.; Wesolowska, O. Increased lipid peroxidation, apoptosis and selective cytotoxicity in colon cancer cell line LoVo and its doxorubicin-resistant subline LoVo/Dx in the presence of newly synthesized phenothiazine derivatives. Biomed. Pharmacother. 2018, 106, 624-636. [CrossRef] [PubMed]

51. Zarkovic, N. Roles and functions of ROS and RNS in cellular physiology and pathology. Cells 2020, 9, 767. [CrossRef] [PubMed]

52. Gasparovic, A.C.; Milkovic, L.; Sunjic, S.B.; Zarkovic, N. Cancer growth regulation by 4-hydroxynonenal. Free Radic. Biol. Med. 2017, 111, 226-234. [CrossRef] [PubMed]

53. Breitzig, M.; Bhimineni, C.; Lockey, R.; Kolliputi, N. 4-Hydroxy-2-nonenal: A critical target in oxidative stress? Am. J. Physiol. Cell Physiol. 2016, 311, C537-C543. [CrossRef]

54. Zarkovic, N. Antioxidants and second messengers of free radicals. Antioxidants 2018, 7, 158. [CrossRef]

55. Jaganjac, M.; Milkovic, L.; Sunjic, S.B.; Zarkovic, N. The NRF2, thioredoxin, and glutathione system in tumorigenesis and anticancer therapies. Antioxidants 2020, 9, 1151. [CrossRef] 
56. Sehrawat, A.; Samanta, S.K.; Hahm, E.R.; Croix, C.S.; Watkins, S.; Singh, S.V. Withaferin A-mediated apoptosis in breast cancer cells is associated with alterations in mitochondrial dynamics. Mitochondrion 2019, 47, 282-293. [CrossRef]

57. Yan, Z.; Guo, R.; Gan, L.; Lau, W.B.; Cao, X.; Zhao, J.; Ma, X.; Christopher, T.A.; Lopez, B.L.; Wang, Y. Withaferin A inhibits apoptosis via activated Akt-mediated inhibition of oxidative stress. Life Sci. 2018, 211, 91-101. [CrossRef]

58. Widodo, N.; Priyandoko, D.; Shah, N.; Wadhwa, R.; Kaul, S.C. Selective killing of cancer cells by Ashwagandha leaf extract and its component Withanone involves ROS signaling. PLoS ONE 2010, 5, e13536. [CrossRef]

59. Kim, G.; Kim, T.H.; Hwang, E.H.; Chang, K.T.; Hong, J.J.; Park, J.H. Withaferin A inhibits the proliferation of gastric cancer cells by inducing G2/M cell cycle arrest and apoptosis. Oncol. Lett. 2017, 14, 416-422. [CrossRef] [PubMed]

60. Lv, T.Z.; Wang, G.S. Antiproliferation potential of withaferin A on human osteosarcoma cells via the inhibition of G2/M checkpoint proteins. Exp. Ther. Med. 2015, 10, 323-329. [CrossRef] [PubMed]

61. Okamoto, S.; Tsujioka, T.; Suemori, S.; Kida, J.; Kondo, T.; Tohyama, Y.; Tohyama, K. Withaferin A suppresses the growth of myelodysplasia and leukemia cell lines by inhibiting cell cycle progression. Cancer Sci. 2016, 107, 1302-1314. [CrossRef] [PubMed]

62. Zhang, X.; Mukerji, R.; Samadi, A.K.; Cohen, M.S. Down-regulation of estrogen receptor-alpha and rearranged during transfection tyrosine kinase is associated with withaferin A-induced apoptosis in MCF-7 breast cancer cells. BMC Complement. Altern. Med. 2011, 11, 84. [CrossRef] [PubMed]

63. Roy, R.V.; Suman, S.; Das, T.P.; Luevano, J.E.; Damodaran, C. Withaferin A, a steroidal lactone from Withania somnifera, induces mitotic catastrophe and growth arrest in prostate cancer cells. J. Nat. Prod. 2013, 76, 1909-1915. [CrossRef] [PubMed]

64. Park, J.W.; Min, K.J.; Kim, D.E.; Kwon, T.K. Withaferin A induces apoptosis through the generation of thiol oxidation in human head and neck cancer cells. Int. J. Mol. Med. 2015, 35, 247-252. [CrossRef]

65. Choi, M.J.; Park, E.J.; Min, K.J.; Park, J.W.; Kwon, T.K. Endoplasmic reticulum stress mediates withaferin A-induced apoptosis in human renal carcinoma cells. Toxicol. In Vitro 2011, 25, 692-698. [CrossRef]

66. Yu, Y.; Hamza, A.; Zhang, T.; Gu, M.; Zou, P.; Newman, B.; Li, Y.; Gunatilaka, A.A.; Zhan, C.G.; Sun, D. Withaferin A targets heat shock protein 90 in pancreatic cancer cells. Biochem. Pharmacol. 2010, 79, 542-551. [CrossRef]

67. Falsey, R.R.; Marron, M.T.; Gunaherath, G.M.; Shirahatti, N.; Mahadevan, D.; Gunatilaka, A.A.; Whitesell, L. Actin microfilament aggregation induced by withaferin A is mediated by annexin II. Nat. Chem. Biol. 2006, 2, 33-38. [CrossRef] [PubMed]

68. Liu, W.; Wang, G.; Palovcak, A.; Li, Y.; Hao, S.; Liu, Z.J.; Landgraf, R.; Yuan, F.; Zhang, Y. Impeding the single-strand annealing pathway of DNA double-strand break repair by withaferin A-mediated FANCA degradation. DNA Repair 2019, 77, 10-17. [CrossRef] [PubMed] 